Obszerna bibliografia przedmiotu, może być przydatna dla potencjalnego czytelnika jako użyteczny przewodnik po zlożonej drodze rozwoju badań z zakresu dziejów myśli pedagogicznej.

Praca S. Sztobryna jest przykładem interesujacego sposobu uprawiania historii doktryn i myśli pedagogicznej $w$ powiązaniach $\mathrm{z}$ historia, filozofia i teoriami pedagogicznymi. Wydaje się, iż glówny wkład Autora polega na tym, że zaprezentował spojrzenie krytyczno-syntetyczne na dorobek polskiej historiografii $z$ lat 1900 - 1939 oraz zademonstrowal nowa interpretacje analizowanych źródeł. Od strony merytorycznej Autor wprowadza i określa wkład w dzieje myśli pedagogicznej autorów dotąd nieznanych, nie uwzględnianych w żadnych opracowaniach syntetycznych z zakresu myśli pedagogicznej, takich jak: K. Banszel, M. Bienenstock, P. Chomicz, F. Fidziński, M. Friedlander, W. Hahn, M. Mituła, M. Orłow i inni. Za nowatorskie poszukiwania badawcze należy uznać także umiejętne określanie orientacji metodologicznej w twórczości badanych przedstawicieli, określanie odmiennych stylów i metod badań, czy ukazywanie ewolucji w interpretacji dziejów myśli pedagogicznej, jak również trójwymiarowa i dynamiczna strukturę narracji z uwzględnieniem trzech aspektów: problemowego, przekrojowego i metodologicznego.

Łucja Kabzińska

\title{
Włodzimierz Tyburski, Myśl etyczna w Polsce od XVI do XIX wieku, Toruń 2000, ss. 578
}

W polskiej historiografii oświatowo-wychowawczej jest wiele publikacji, których autorami są filozofowie, historycy filozofii lub etycy. Wystarczy przywołać nazwiska takich twórców, jak: L. Chmaj, I. Halpern-Myślicki, M. Straszewski, B. Suchodolski, W. Wąsik i in.. Historycy pedagogiki wyróżniaja w dziejach rozwoju myśli pedagogicznej nurt nazywany filozoficznym lub filozoficzno-etycznym. Do tego nurtu niewatpliwie wpisuje się ksiażka Włodzimierza Tyburskiego zatytułowana Myśl etyczna w Polsce, w której czytelnik odnajdzie wiele interesujacych rozważań na temat rozwoju myśli pedagogicznej na przestrzeni czterech wieków. Naturalną rzecza jest to, że nie poddaję omówieniu i ocenie całości pracy, gdyż dokonają tego w sposób profesjonalny historycy filozofii. Pragnę jedynie zwrócić uwage na te wątki, zreszta liczne w tej pracy, które odnoszą się do dziejów polskiej filozofii wychowania na przestrzeni wyróżnionych wieków. Zajmują one znaczące fragmenty omawianej pracy i dla historyka wychowania moga stanowić ważne źródło poznawcze.

Praca składa się z 5 rozdziałów obrazujących rozwój nurtów etycznych poszczególnych epok. Poprzedza je Przedmowa, w której Autor przedstawia: główne źródła w oparciu, o które zrealizowane zostały poszczególne zagadnienia oraz zasa- dy opracowania podjętego tematu. Przedstawiajac założenia swojej pracy W. Tyburski pisze: „Zamiarem autora opracowania jest ukazanie dziejów nowożytnej myśli etycznej w Polsce zarówno w jej złożonej strukturze problemowej, jak i w kontekście wydarzeń intelektualnych, kulturowych i spolecznych" (s. 6). Autor w swoich analizach nie ogranicza się jedynie do poglądów etycznych zawartych w traktatach filozoficznych myślicieli poszczególnych epok. Wątki etyczne wydobywa także z piśmiennictwa społecznego, politycznego, literackiego i oświatowego. Przykładowo omawiając źródła rekonstrukcji przedstawianych poglądów W. Tyburski pisze: „Wiedzy o etyce polskiej doby renesansu dostarcza również analiza programów nauczania filozofii w szkolnictwie powszechnym drugiej polowy XVI wieku. Filozofia, a $w$ jej ramach etyka, wykładana była w szkolach różnowierczych, jak i katolickich, zwłaszcza jezuickich" (s. 7).

Część zasadniczą rozważań wynikająca z zakreślonego tematu poprzedza Wprowadzenie, w którym skrótowo przedstawione zostały poczatki myśli etycznej (filozofii moralnej) w Polsce i jej najwybitniejsi przedstawiciele.

Rozdział I pt. Filozofia moralna polskiego Odrodzenia przedstawia rozwój filozofii moralnej poprzez działalność i poglady uczonych Akademii 
Krakowskiej z jej glównym reprezentantem Szymonem Marycjuszem z Pilzna. Idee etyczne odnajduje Autor w szkolnictwic różnowierczym i jezuickim, wskazując na ich praktyczny charakter wynikający nie tylko $\mathrm{z}$ normatywnego ich charakteru, lecz także $\mathrm{z}$ faktu realizacji w praktyce edukacyjnej wymienionych rodzajów szkół. Na całość wizerunku myśli etycznej tej epoki składaja się poglądy przedstawicieli myśli politycznej i społecznej, z glosami m.in. takich myślicieli, jak A. Frycz Modrzewski, Ł. Górnicki czy P. Skarga. W sumie na wizerunek myśli etycznej polskiego Odrodzenia, jak wynika z rozważań Autora, składają się idee zawarte w poglądach politycznych, społecznych, religijnych, a także tych, które można nazwać edukacyjnymi.

Pewne podobieństwo, jeżeli chodzi o strukturę i źródła powstania i rozwoju filozofii moralnej, dostrzec można w rozważaniach Autora poświęconych Filozofii moralnej XVII wieku - rozdział II. Filozofię moralną o charakterze uniwersyteckim uzupełniaja idee moralne zawarte $w$ filozofii szkolnej realizowanej w szkolnictwie katolickim i protestanckim. Ważnym odłamem tej refleksji jest myśl etyczna arian i socynjan (zawarta w poglądach m.in. S. Przypkowskiego i A. Wiszowatego). W stuleciu tym myśl etyczna zaznacza swoje miejsce w piśmiennictwie o charakterze polityczno-spolecznym i literackim (A.M. Fredro, L. Opaliński i in). Szczególne miejsce wśród autorów głoszonych poglądów etycznych przypada Sebastianowi Petrycemu z Pilzna. Znawca pism Arystotelesa, był orędownikiem prymatu etyki nad innymi dziedzinami filozofii. W dziejach filozofii wychowania zapisał się jako twórca koncepcji wychowania moralnego.

Szczególnie cennym dla historyka wychowania wydaje się być rozdział III pt. Nauka moralna wieku Oświecenia. Znajdujemy w nim spojrzenie Autora - historyka filozofii na koncepcje i program wychowawczy realizowany w Collegium Nobilium, Szkole Rycerskiej, projektach i działalności Komisji Edukacji Narodowej. Obraz ,nauki moralnej" wieku Oświecenia uzupełniaja idee filozofii moralnej m.in. S. Staszica i braci Jana i Jędrzeja Śniadeckich. Podsumowując rozwaźania dotyczące epoki Oświecenia W. Tyburski stwierdza: „Dla wszystkich nieomal faz rozwoju myśli oświeceniowej charakterystyczne było wysunięcie na pierwszy plan problematyki politycz- no-społecznej konkretyzującej się w programach „naprawy Rzeczypospolitej”. Szczególnie ważne miejsce zajmowaly w niej projekty edukacji obywatelskiej, w ramach, których bardzo wysoką range nadawano wychowaniu moralnemu. Nauka moralna miała być tą dyscypliną, z która wiązano nadzieje na przeorientowanie świadomości moralnej społeczeństwa $w$ duchu postulowanych wartości i zasad" (s. 542).

Zagadnienia oświatowo-wychowawcze zajmowały sporo miejsca w refleksji czasów romantyzmu - rozdział IV pt. Romantyzm (okres mie dzypowstaniowy) a filozofia moralna. Łączac rozwój nauki z sytuacja polityczna narodu autorzy wygłaszanych poglądów tworzyli koncepcje „filozofii narodowej”. W grupie twórców tego nurtu znajduje się autor dzieła pt. Chowanna - czyli system pedagogiki narodowej B. Trentowski, w którym przedstawił propozycje edukacji narodowej. Obok niego na listę reprezentantów tego nurtu wpisali się: A. Cieszkowski, K. Libelt, F. Jezierski $i$ in., dla których problematyka edukacji moralnej społeczeństwa polskiego była szczególnie bliska i znalazła odzwierciedlenie $w$ ich pismach. Prócz nurtu narodowego w okresie międzypowstaniowym w rozwoju polskiej etyki zarysowal się nurt konserwatywny, którego przedstawicielkami były m.in. K. Tańska-Hoffmanowa, E. Ziemięcka. Różnorodność poglądów tej epoki uzupełniaja poglądy mesjanistów (A. Mickiewicz, J. Słowacki, Z. Krasiński, C.K. Norwid), dla których naród polski jako naród wybrany miał wskazać światu droge do moralnej odnowy.

Ostatni, rozdział V, pt. Etyka epoki pozytywizти i przetomu antypozytywistycznego jest wykładem poświęconym zagadnieniom uzyskiwania przez etykę autonomicznego charakteru. Zawiera rozważania na temat projektów etyki jako dyscypliny usamodzielniającej się i wyodrębniającej się z filozofii. Prócz różnych koncepcji rozumienia etyki, jej przedmiotu badań, jej funkcji i zadań oraz kontrowersji z tym zwiazanych, Autor przedstawia pozytywistyczne koncepcje oświatowe i wychowawcze. Bowiem w dązeniach pozytywistów służących zbudowaniu etyki naukowej, obok zadań teoretycznych wychodzono z propozycjami realizacji określonych idei w praktyce. Powszechnie znanym jest, iż niezwykle ważnym elementem programu pozytywistów były propozycje oświatowe, a szczególne znaczenie nadawano zagad- 
nieniom wychowania moralnego. Wg ustaleń Autora ,Nowe ideały, zestawy cnot oraz wzory osobowe stanowić miały rodzaj drogowskazów, według których miał postępować rozwój jednostki i spoleczeństwa. Wzgląd na użyteczność zadecydowal, że przedstawiciele tego ruchu stali się zwolennikami niektórych propozycji etyki utylitamej" (s. 545).

W sumie, lektura ksiażki Profesora W. Tyburskiego dowodzi jak ważnym elementem pol- skich koncepcji edukacyjnych były idee moralne. Nie jest to jednak jednostronna relacja, bowiem z rozważań Autora wynika, iż prawie zawsze polskie koncepcje etyczne tworzono z myślą o edukacji narodu polskiego i ,naprawie Rzeczypospolitej". Dlatego też omawiana publikacja jest godna polecenia nie tylko tym, którzy interesuja się dziejami etyki, ale także tym, którzy pragna poznać polskie tradycje wychowania moralnego.

Wladystawa Szulakiewicz

\section{Noty}

\section{Lech Mokrzecki, Wokół staropolskiej nauki i oświaty, Wydaw- nictwo Gdańskie, Gdańsk 2001, ss. 486}

Wybitny gdański historyk oświaty i nauki okresu staropolskiego Lech Mokrzecki przez lata wiele publikował na różnych lamach. Teraz część $z$ tych cennych rozpraw drukowanych $w$ rozmaitych czasopismach specjalistycznych, regionaInych, czasami trudno dostępnych została zebrana i opublikowana w omawianym tomie przez Wydawnictwo Gdańskie.

Autor, jak zaznacza we wstępie, dokonał w pierwotnych tekstach wielu poprawek i zmian, dążac do uaktualnienia zawartych $w$ rozważaniach, powstających przecież w ciagu wielu lat poszukiwań i pracy naukowej, danych, opinii i poglądów. Tak więc otrzymujemy tom zawierajacy znane już teksty, ale w nowym ujęciu i, co bardzo cenne i wygodne dla czytelnika, zebrane razem. Tom obejmuje imponujaca ilość tekstów uzupełniona bibliografia prac L. Mokrzeckiego za okres 1996-2000 (wcześniejsze prace zostały zebrane w bibliografii dołaczonej do Księgi ofiarowanej profesorowi Mokrzeckiemu z okazji jubileuszu trzydziestolecia pracy naukowej i sześćdziesiatych urodzin wydanej w Gdańsku w 1996 roku pod tytułem Szlakami przesztości i czasów wspótczesnych).

32 teksty zawarte $w$ omawianym tomie poruszające zasadniczo tematykę dziejów oświaty i nauki w dawnym Gdańsku, można podzielić na kilka grup omawiających zbliżoną tematykę i jednocześnie wyznaczajacych główne kierunki badań i zainteresowań autora.

Pierwsza grupa obejmuje teksty omawiające zagadnienia ogólne, takie jak chronologiczne ujęcie dziejów gdańskiej oświaty, rolę nauki i oświaty w życiu mieszczan gdańskich, wizje nauki i oświaty dawnych uczonych.

Druga zawiera rozważania o działalności i twórczości uczonych gdańskich. Tutaj autor omawia m.in. problematyke morską $w$ pracach Reinholda Curicke, twórczość wybitnego prawnika i historyka Jana Schultza-Szuleckiego, następnie Joachima Hoppego i jego bratanka Samuela Joachima, dwóch wybitnych przedstawicieli nauki historycznej. Obok omówienia rozważań Samuela Fryderyka Willenberga na temat nauki i edukacji znajdujemy również przedstawienie sylwetki innego wybitnego uczonego związane z Gdańskiem - historyka, pedagoga, profesora Gdańskiego Gimnazjum Akademickiego Joachima Pastoriusa. Z ta szkoła związani byli także prezentowani w omawianym tomie Jerzy Wende, Bartomiej Keckermann. Wśród sylwetek uczonych widzimy również Jana Amosa Komeńskiego, wprawdzie nie zwiazanego z Gdańskiem w taki sposób jak wymienieni wyżej uczeni, ale będącego znacząca 